\title{
FASILITAS USAHA MAKANAN POST COVID
}

\author{
Irene Winsome1), Budi A Sukada ${ }^{2)}$ \\ 1)Program Studi S1 Arsitektur, Fakultas Teknik, Universitas Tarumanagara, irenewinsome98@gmail.com \\ 2) Program Studi S1 Arsitektur, Fakultas Teknik, Universitas Tarumanagara, budisukada@yahoo.com
}

\begin{abstract}
Abstrak
Pandemic Covid-19 yang menyerang seluruh penduduk dunia memberikan dampak bagi masyarakat. Penyebaran virus Covid-19 yang sangat cepat memaksa masyarakat tidak saling berinteraksi dan berdiam diri di rumah. Hal ini menyebabkan berubahnya cara berhuni masyarakat, timbulnya gaya hidup baru, dan kebiasaan baru seperti physical distancing, work from home, dan school from home. Masyarakat dipaksa untuk dapat beradaptasi dengan perubahan yang sangat cepat. Untuk menekan penyebaran virus, pemerintah Jakarta memberlakukan kebijakan pembatasan sosial berskala besar (PSBB). Dengan berlakunya kebijakan ini, banyak kegiatan dari masyarakat yang lumpuh, banyak usaha yang tutup, dan merumahkan banyak tenaga kerja dari sektor formal ataupun non formal. Hal ini menyebabkann turunnya ekonomi masyarakat. Perekonomian masyarakat yang turun karena adanya covid-19 mendorong masyarakat lebih memfokuskan pengeluaran pada kebutuhan pokok, sementara konsumsi lainnya yang tidak bersifat prioritas menurun. Melihat tren bisnis kuliner yang bermunculan saat pandemic ini, dan juga perilaku konsumsi generasi $Y$ dan $Z$, maka usaha tersebut perlu difasilitasi dengan wadah yang dapat memenuhi kegiatan produksi, dan pemasaran. Fasilitas usaha makanan memfasilitasi dan melaksanakan kegiatan-kegiatan yang berhubungan dengan kegiatan produksi, distribusi, dan penjualan. Fasilitas usaha makanan post covid-19 mewadahi start-up bisnis kuliner, usaha katering, dan wirausaha makanan lainnya. Dengan keberadaan fasilitas usaha makanan ini, diharapkan dapat membangkitkan ekonomi masyarakat.
\end{abstract}

Kata kunci: Covid-19; Ekonomi; Fasilitas; Kuliner

\begin{abstract}
Covid-19 pandemic, that hit the entire world population, has an impact on society. the transmission of the virus is done so fast forcing people not to interact with others and stay at home. This situation has led to changes in the way people live, the emergence of new lifestyles, and new habits such as physical distancing, work from home, and school from home. People are being forced to be able to adapt to very fast changes. To prevent virus transmission, the Jakarta Government has implemented "Pembatasan Sosial Berskala Besar (PSBB)". This policy makes many activities paralyze, many businesses have closed, and laid off many workers from the formal and non-formal sectors. This situation causes an economic decline. The decline in society's economy due to Covid-19 has encouraged people to be more focused on spending on basic needs while other consumption that is not a priority has decreased. Seeing the culinary business trends that have emerged during this pandemic, as well as the consumption behavior of generations $Y$ and $Z$, this business needs to be facilitated to fulfill production and marketing activities. Food Service Facility facilitates and carry out activities related to the production, distribution, sale of food products. Food Service Facility accommodates culinary business start-ups, catering businesses, and other food entrepreneurs. With this Food Service Facility existence hoped can help to improve the economy
\end{abstract}

Keywords: Covid-19; Culinary; Economy; Facility 


\section{PENDAHULUAN}

\section{Latar Belakang}

Dwelling dari kata "dwell"diterjemahkan sebagai tinggal, Bermukim, atau berhuni. Kata Dwelling dalam Bahasa inggris kunonya 'dwellan' memilki arti mengembara (to Wander), dan bertahan hidup (to linger). Maka Kata Dwelling memberikan makna untuk bertahan hidup, manusia tidak dapat berdiam diri saja tetapi juga berkelana dan mengembara (Gandha, 2020).

Awal tahun 2020, virus covid-19 menyerang seluruh penduduk di dunia. Menyebarnya virus baru dengan sangat cepat dari manusia ke manusia menyebabkan perubahan pada kebiasaan masyarakat. Jakarta merupakan salah satu kota dengan tingkat penularan cukup tinggi di Indonesia. Untuk menghindari naiknya tingkat penularan virus, pemerintah memberlakukan kebijakan Pembatasan Sosial Berskala Besar (PSBB). Hal ini melumpuhkan berbagai kegiatan masyarakat. Salah satu kegiatan yang terdampak adalah kegiatan ekonomi. Di Indonesia, turunnya ekonomi menyebabkan sebanyak 2 juta pekerja formal maupun non formal yang dirumahkan (Verdiana, 2020). Walaupun banyak kegiatan ekonomi yang lumpuh, bisnis kuliner baru banyak bermunculan saat pandemic ini. Bisnis yang muncul ini kemudian lebih berfokus pada sistem penjualan online. Hal ini dikarenakan bergesernya perilaku konsumen akibat covid19. Tetapi menurut data dari Piper Jaffray, generasi masa kini lebih melihat dunia kuliner sebagai pilihan untuk bersenang-senang dibandingkan untuk memenuhi rasa lapar dan haus (Hasan, 2017).

Untuk meresponi hal-hal tersebut, fasilitas usaha makanan post covid dibentuk agar dapat meningkatkan perekonomian masyarakat. Diharapkan fasilitas usaha makanan ini dapat menjadi wadah bagi usaha kuliner baru maupun lama yang membutuhkan tempat produksi, dan sistem pemasaran yang jelas. Untuk meresponi perilaku generasi $Y$ dan $Z$, fasilitas ini tetap menyediakan tempat dine in yang semi terbuka dan terbuka agar sirkulasi udara tetap lancar. Sedangkan untuk meresponi pergeseran perilaku konsumen akibat covid-19 yang lebih memilih untuk online shopping, fasilitas usaha makanan juga menyediakan tempat penjualan bagi ojek online, dan membedakan sirkulasi dari ojek online, dan pengunjung lainnya agar pengunjung tetap merasa aman.

\section{Rumusan Permasalahan}

Fenomena Covid-19 memberikan berbagai dampak bagi kehidupan manusia. Salah satu dampaknya adalah ekonomi masyaraat yang turun. Hal ini menyebabkan jumlah konsumsi masyarakat yang menurun.

a. Bagaimana Arsitektur dapat menciptakan wadah baru bagi masyarakat untuk memperbaiki keadaan ekonomi, dan meresponi tren yang muncul karena covid-19?

b. Bagaimana solusi untuk menghadirkan ruang baru yang sifatnya responsif usaha kuliner yang bermunculan, dan memberikan peluang bagi masyarakat yang terdampak Pandemic Covid-19?

\section{Tujuan}

Menciptakan karya arsitektur yang dapat mewadahi pemenuhan kebutuhan masyarakat, dan diharapkan dapat menaikan perekonomian masyarakat. Juga memfasilitasi start-up kuliner, usaha katering, dan wirausahawan makanan lainnya sebuah tempat produksi yang memadai.

\section{Target dan Sasaran}

Proyek ini ada karena kebutuhan masyarakat untuk survive (bertahan hidup). Hal ini dilakukan untuk pemenuhan kebutuhan manusia. Proyek ini ditujukan untuk masyarakat kota jakarta khususnya Jakarta Barat dan Jakarta utara untuk bangkit dari keterpurukan ekonomi akibat Pandemic covid-19. 
Kelurahan Kamal Muara, Penjaringan, Jakarta utara merupakan daerah industri yang ada di daerah PIK. Daerah ini dekat dengan daerah hunian padat di Jakarta Barat, dan perumahan Manyar Permai PIK. Proyek yang diusulkan dapat membuka lapangan pekerjaan bagi masyarakat sekitar tapak dan kemudian produk yang dihasilkan akan dijual dan target pasarnya adalah generasi $Y$ dan $Z$ yang hidup serba praktis.

\section{KAJIAN LITERATUR}

\section{Dwelling}

Proses terciptanya dwelling terjadi berulang kali (experiment), dilakukan agar mencapai tujuan yang diinginkan atau menyesuaikan dengan konteksnya (Gandha, 2020). Dwelling merupakan adaptasi dan bersifat eksperimentatif. Dwelling dalam perilaku manusia dilakukan secara permanen dengan tujuan survival. Dalam perkembangannya, dwelling berkaitan erat dengan konsep waktu (time), konsep ruang (space), konsep tempat (place), dan konsep untuk hidup (to live) (Gandha, 2020). Konsep dwelling dari waktu ke waktu mengalami perubahan sesuai dengan lingkungannya. Dwelling merupakan bagian dari kehidupan manusia dari masa ke masa. Sifat dari $d$ well adalah menetap dan tidak nomaden - menetap untuk bertahan hidup (to linger).

Menurut heideger (1971) dalam bukunya yang berjudul "Building, Dwelling, Thinking", cara kita tinggal/ hidup adalah cara dimana kita berada, realitas kita ada di muka bumi merupakan perpanjangan identitas kita dan tentang siapa diri kita sesungguhnya. Menurut Heideger, tidak semua bangunan merupakan dwelling. Tapi tujuan dari building adalah dwelling. Terdapat 4 (empat) komponen dwelling merurut Heideger (Fourfold) (Austronaldo, 2012), yaitu: Mortal (manusia), Earth, Sky, dan Divinities (kekuatan supranatural).

Mortal melakukan dwelling dengan menjaga kesatuan dari keempat elemen dwelling tersebut yaitu dengan (Heidegger, 1971):

- Menjaga bumi,

- Menerima langit sebagai langit (manusia harus menjaga keseimbangan alam), dan

- Tidak mengubah "kekuatan supranatural" yang dipercayai menjadi duniawi (seperti menganggap uang sebagai Tuhan dan memujanya terutama di era modern).

Menurut Christian Noberg-schulz, dwelling mempunyai makna yang lebih dalam dari sekedar atap yang menaungi di atas kepala dan sejumlah meter persegi ruang yang kita miliki (Sjarief, 2020). 4 tahapan dwelling menurut Christian Noberg-Schulz (Austronaldo, 2012):

- Settlement; tahapan awal"berhuni"

- Urban Space; Tahap kedua dimana manusia bertemu dalamkeberagamannya.

- Institution / Public Dwelling; bangunan publik menjadi perwujudan dari "berhuni" publik, tempat dimana manusia memiliki kesamaan dan membentuk komunitas.

- House / Private Dwelling; tahap akhir yang menjadi tempat peristirahatan pribadi dimana individu hidup dengan damai dalam dunia ciptaannya.

\section{Fasilitas Usaha}

Fasilitas merupakan segala sesuatu yang bertujuan untuk memudahkan dan melancarkan jalannya suatu usaha, dapat berupa benda maupun uang (Wahyuningrum, n.d.). Fasilitas dibedakan menjadi 2 yaitu (Wahyuningrum, n.d.):

- Fasilitas fisik; merupakan sesuatu berupa benda atau apapun yang dapat dibendakan, yang mempermudah dan melancarkan suatu usaha. Fasilitas fisik disebut juga dengan fasilitas materil. Fasilitas ini diperlukan sebelum suatu kegiatan berlangsung, karena digunakan untuk memudahkan dan melancarkan.

- Fasilitas uang; merupakan segala sesuatu yang memberi kemudahan karena adanya nilai uang. 


\section{Makanan}

Makanan merupakan kebutuhan yang diperlukan setiap saat oleh manusia. Makanan perlu diolah dengan baik dan benar agar dapat memberikan manfaat bagi tuhuh. Produk makanan merupakan segala sesuatu yang diolah maupun yang tidak diolah, bersumber dari hayati dan air yang dikonsumsi manusia (Saparinto \& Hidayati, 2010).

Berdasarkan cara memperolehnya, pangan dibedakan menjadi 3 macam yaitu (Nurdin, 2017):

- Pangan segar

Merupakan pangan yang belum mengalami pengolahan (dapat dikonsumsi langsung)

- Pangan olahan

Merupakan makanan yang sudah diolah dengan cara atau metode tertentu dengan atau tanpa bahan tambahan.

- Pangan olahan tertentu

Merupakan pangan yang digunakan oleh kelompok tertentu sebagai upaya pemeliharaan kesehatan.

\section{Cloud Kithcen}

Cloud kithen yang sering disebut sebagai dapur satelit atau ghost kitchen. Cloud kitchen merupakan restoran dengan konsep yang hanya menawarkan jasa delivery saja dan tidak menyediakan tempat makan (Wednesyuda, 2020). Didalamnya tersedia ruang kerja berupa dapur besar dengan fasilitas lengkap yang bisa digunakan untuk memasak berbagai menu makanan dari berbagai restoran. Konsep dapur ini mirip dengan konsep co-working space, tetapi dalam bentuk dapur (Teguh, 2020). Restoran dnegan konsep cloud kithcen ini biasanya bekerja sama dengan layanan pesan antar (Wednesyuda, 2020). Konsep ini awalnya muncul di India. Tahun 2003, Rebel Foods dan Sequoia memulai bisnisnya (Teguh, 2020). Pesatnya permintaan konsumen untuk layanan delivery makanan, menyebabkan konsep cloud kitchen banyak diterakpan.

\section{METODE}

Metode perancangan yang digunakan adalah preseden. Dalam Kamus Webster Merriam, 'preseden' didefinisikan sebagai sesuatu yang dilakukan atau dikatakan yang dapat berfungsi sebagai contoh atau aturan untuk mengesahkan serta membenarkan suatu tindakan selanjutnya dari jenis yang sama dapat dibayangkan sebagai sebuah analogi (pembentukan kata baru dari kata yang telah ada (Sutanto, 2020).

Dalam proyek ini, metode perancangan preseden digunakan dalam mendesain dapur dengan sistem Cloud Kitchen, tetapi tetap menyediakan tempat dine in. Metode tersebut digunakan untuk menstudi bentuk, sirkulasi, dan hal apa saja yang dibutuhkan dari sebuah Cloud Kitchen, dengan tujuan untuk memenuhi kebutuhan user atau pengguna dan dapat menciptakan kenyamanan bagi user atau pengguna dalam pemakaian sehari-hari.

\section{DISKUSI DAN HASIL}

\section{Penjelasan Proyek}

Dari isu dampak Covid-19 yang dibahas, tujuan dari proyek ini adalah untuk menaikan ekonomi masyarakat, dan juga menjadi wadah bagi bisnis start-up kuliner, katering, dan wirausahawan makanan lainnya. Juga dari prediksi yang ada, tentang perilaku konsumen yang akan bergeser pada kebutuhan pokok, dan pembelian online yang meningkat. Sehingga program utama dari proyek ini adalah Kitchen, eating corner, dan online delivery corner.

Dalam proyek ini terdapat area produksi makanan yang akan digunakan oleh start-up kuliner, katering dan wirausahawan makanan lainnya, yang hasilnya akan dijual secara online maupun offline. 


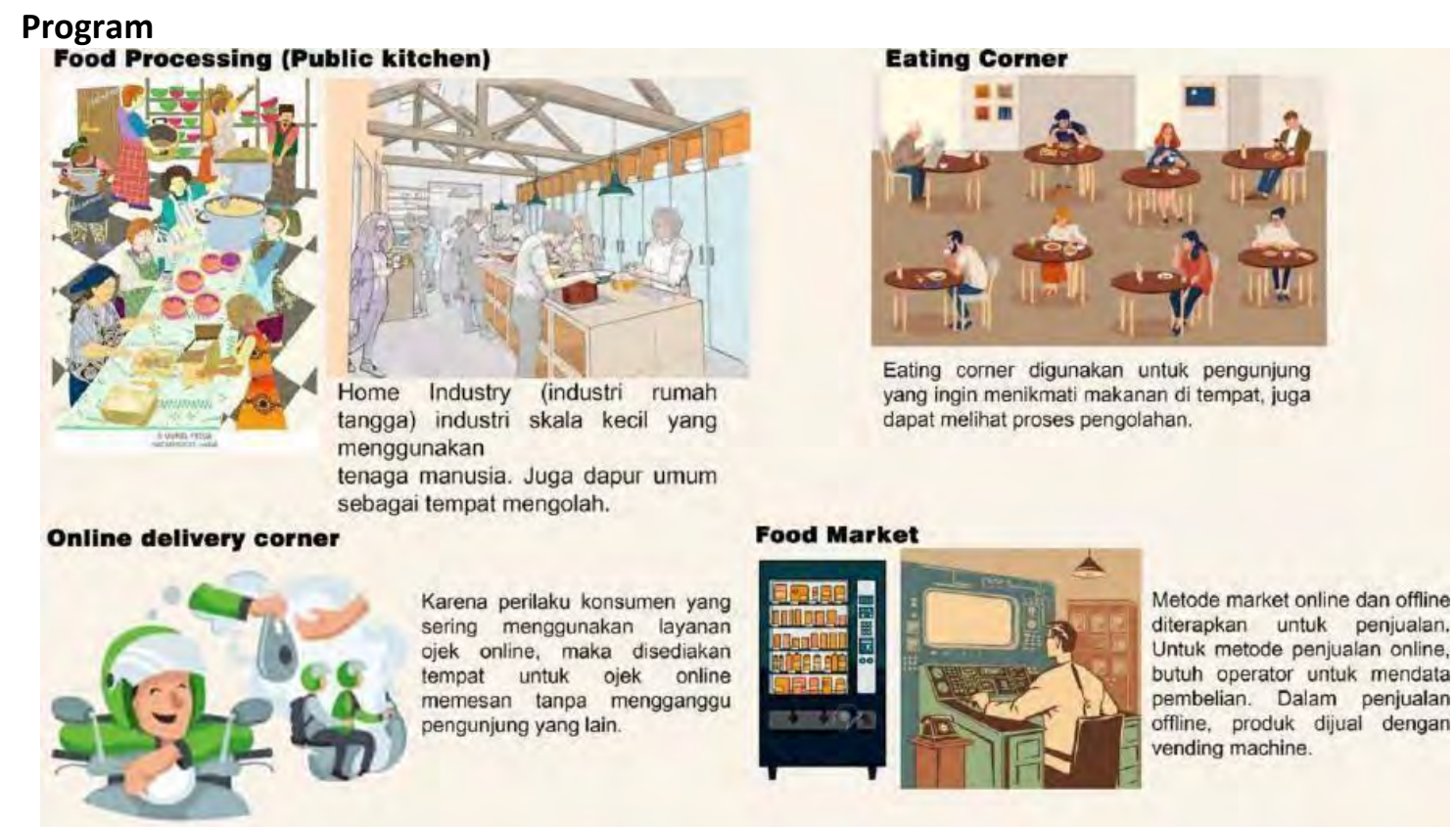

Gambar 1. Program

Sumber: Diolah dari Google.com, 2020

Program dari Fasilitas Usaha makanan ini merupakan respon dari perilaku masyarakan terutama generasi $Y$ dan $Z$ yang terpengaruh karena adanya Covid-19. Program utama dari Fasilitas Usaha Makanan adalah Public Ktichen yang menyediakan fasilitas pendukung bagi usaha kuliner, juga menyediakan fasilitas layanan antar (Online Delivery Corner) untuk merespon kebiasaan baru yang timbul karena Covid-19 dimana masyarakat lebih memilih belanja online. Eating corner disediakan untuk pengunjung yang tetap ini dine in karena dilihat dari cara generasi $Y$ dan $Z$ melihat dunia kuliner sebagai pilihan untuk bersenang-senang.

\section{Sirkulasi}

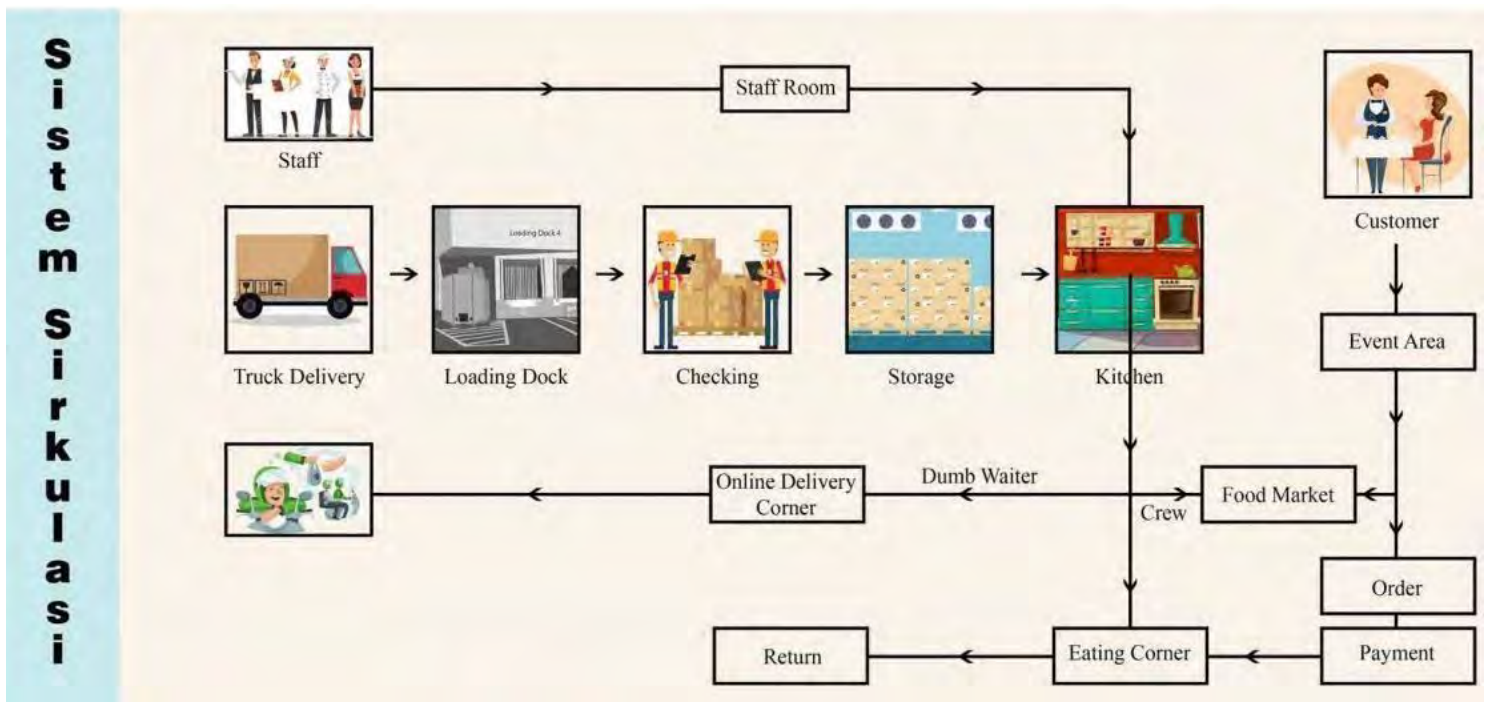

Gambar 2. Sirkulasi

Sumber: Pribadi, 2020 


\section{Identifikasi Pengguna}

\section{Target Pengguna}

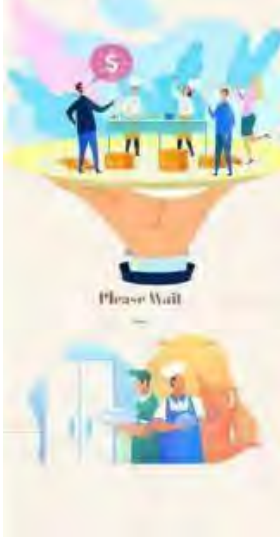

Public kitchen sebagai tempat memasak berbagai jenis makanan yang akan dijual. Public kitchen disewa oleh startup bidang kuliner yang membutuhkan dapur untuk mengolah makanannya. untuk penjualannya dapat dilakukan offline dan online.

Public Kitchen disewakan kepada startup bisnis kuliner yang bermunculan saat pandemic covid-19, juga disewakan kepada bisnis usaha makanan seperti catering, dan wirausahawan makanan.

\section{Target Pengunjung}

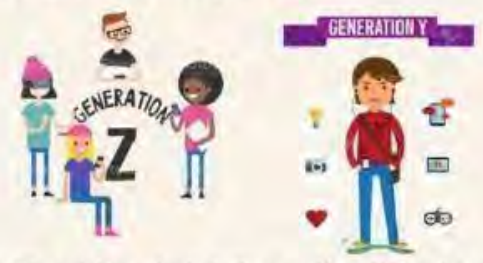

Dari data Piper Jaffray, dunia kuliner makin dilihat sebagai pilihan untuk bersenang-senang oleh generasi masa kini dibandingkan untuk memenuhi rasa lapar dan haus.

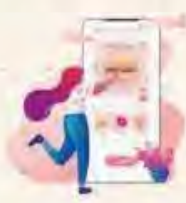

Belanja Online semakin diminati oleh masyarakat di fase normal baru, terutama layanan pesan antar makanan dan bahan pokok. Ketua Asosiasi Modal Ventura untuk Startup Indonesia mengatakan Pandemi Covid-19 ini membuat perilaku konsumen bergeser ke layanan online.

Gambar 3. Target Pengguna dan Pengunjung Sumber: Pribadi, 2020

Target pengguna dari Fasilitas Usaha Makanan ini adalah Start-up bidang kuliner yang bermunculan saat Pandemic Covid-19 yang membutuhkan tempat usaha, catering, dan wirausahawan makanan lainnya. Sedangkan target pengunjung dari project ini adalah generasi $Y$ dan Z yang melihat dunia kuliner sebagai pilihan untuk bersenang-senang dibandingkan sebagai pemuas rasa lapar dan haus. Juga Ojek online, dimana saat Pandemic Covid-19 memberikan dampak yang positf bagi belanja online terutama layanan pesan antar makanan.

\section{Tapak}

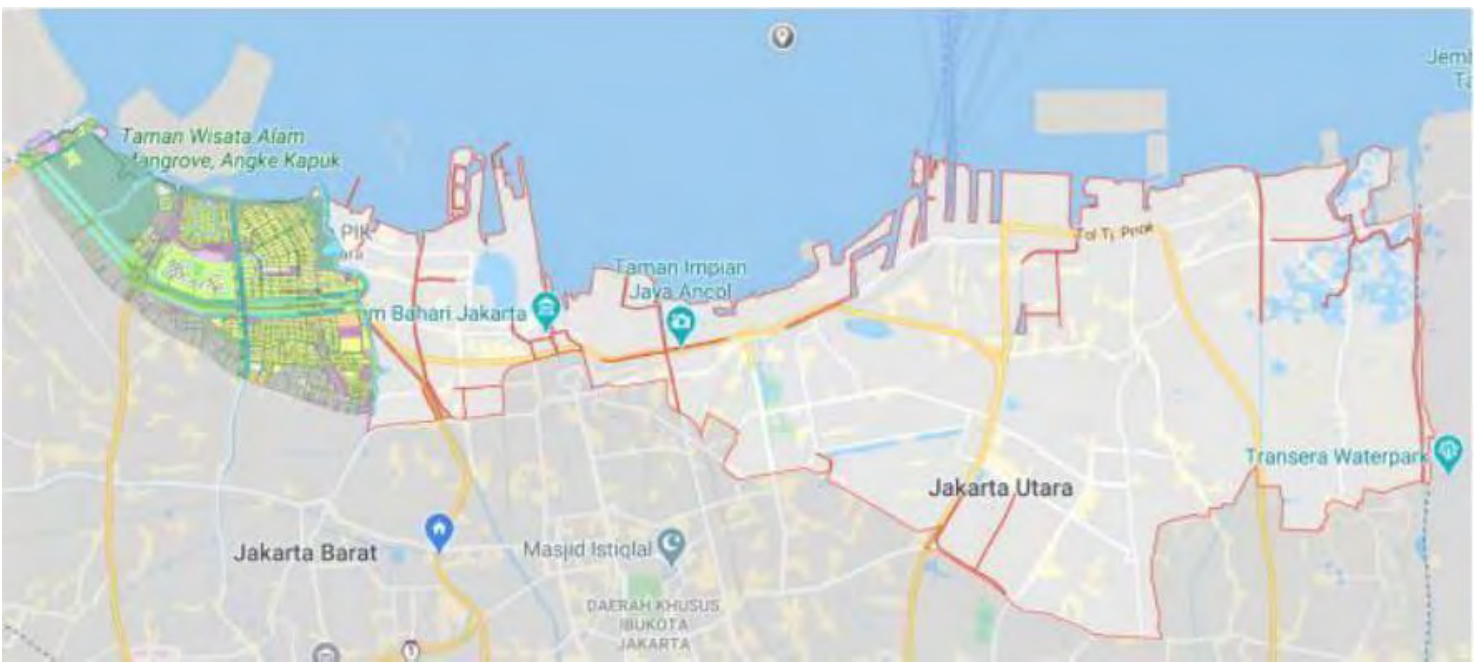

Gambar 4. Jakarta Utara

Sumber: Diolah dari Google Maps, 2020

Untuk lokasi terpilih berada di Kelurahan Kamal Muara Jakarta Utara. Kelurahan Kamal Muara dinilai memenuhi kriteria yaitu

- Tapak berada di jalan besar

Tapak berada di jalan Pantai Indah Selatan dan dekat dengan jalan tol lingkar Luar dan Jalan tol Sedyatmo.

- Tapak dekat dengan pemukiman penduduk

Pemukikan penduduk dekat tapak terdiri dari pemukiman penduduk kecamatan cengkareng, dan dekat dengan perumahan PIK. 
- Daerah tapak merupakan daerah yang sering didatangi oleh generasi $Y$ dan Z. Daerah tapak merupakan daerah PIK yang sering dikunjungi oleh generasi $Y$ dan $Z$ untuk bersenangsenang.

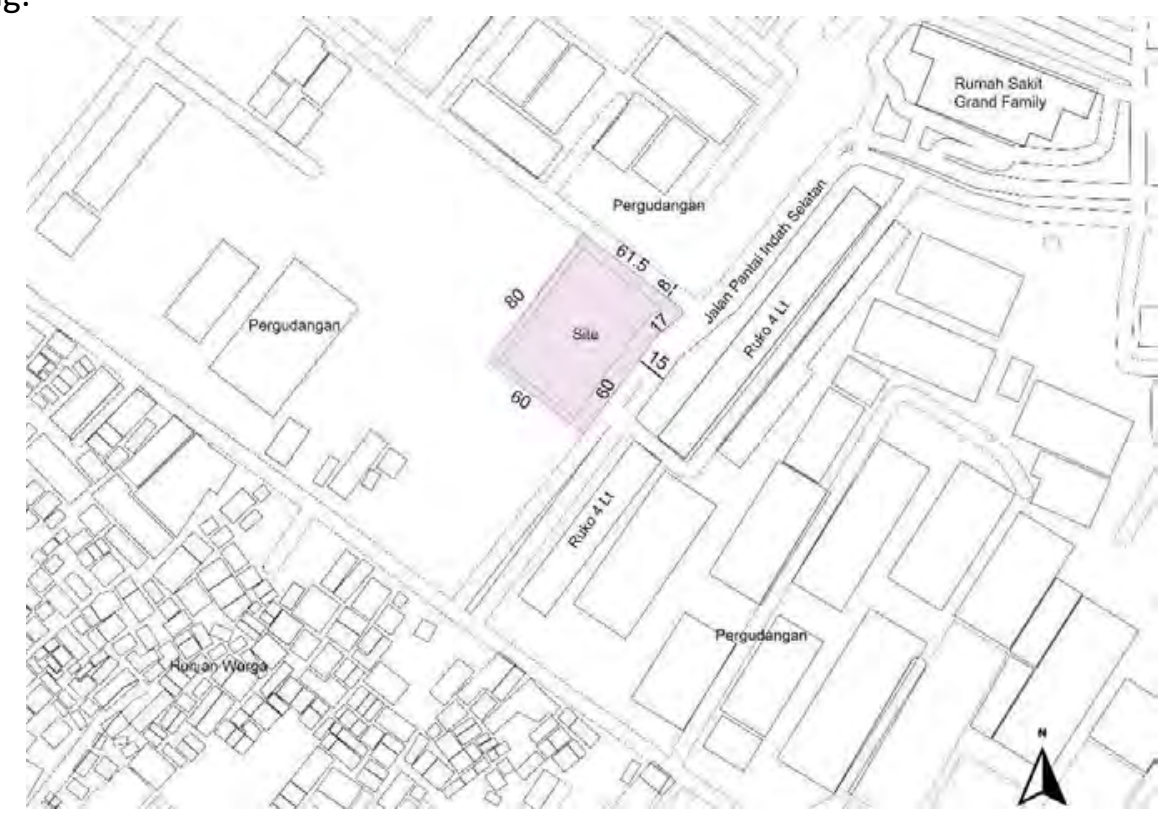

Gambar 5. Profil Tapak

Lokasi Tapak

Luas Tapak

Tata Guna Lahan

KDB/KLB/KB/KDH/KTB : 50\% / 2 / 4 / 35\% / 50\%

Kondisi Tapak Eksisting : Lahan Kosong
: Jalan Pantai Indah Selatan, Kamal Muara, Penjaringan, Jakarta Utara : 4800m2

: Industri dan Pergudangan
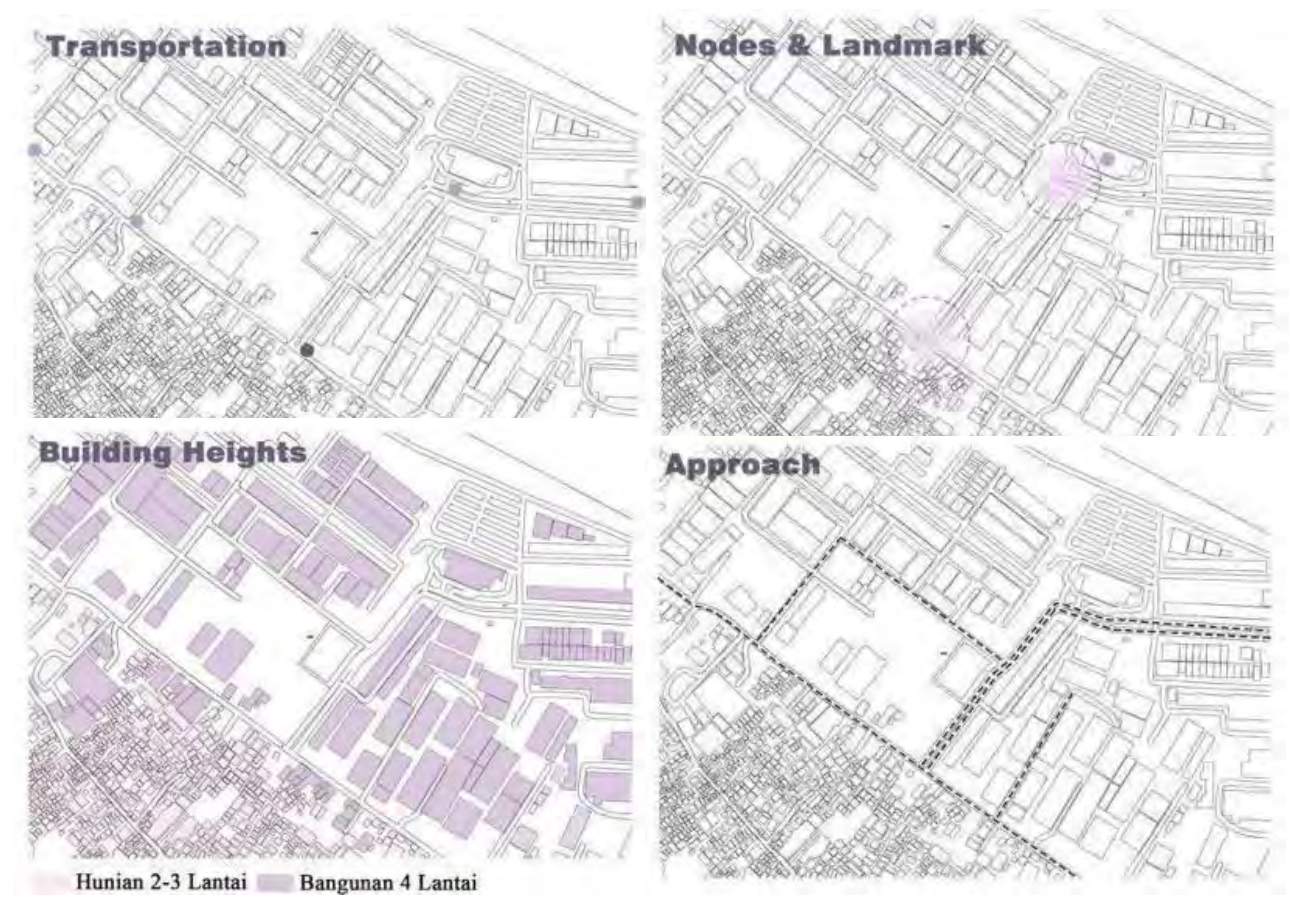

Gambar 6. Analisa Tapak Makro

Sumber: Diolah dari Cadmapper, 2020 


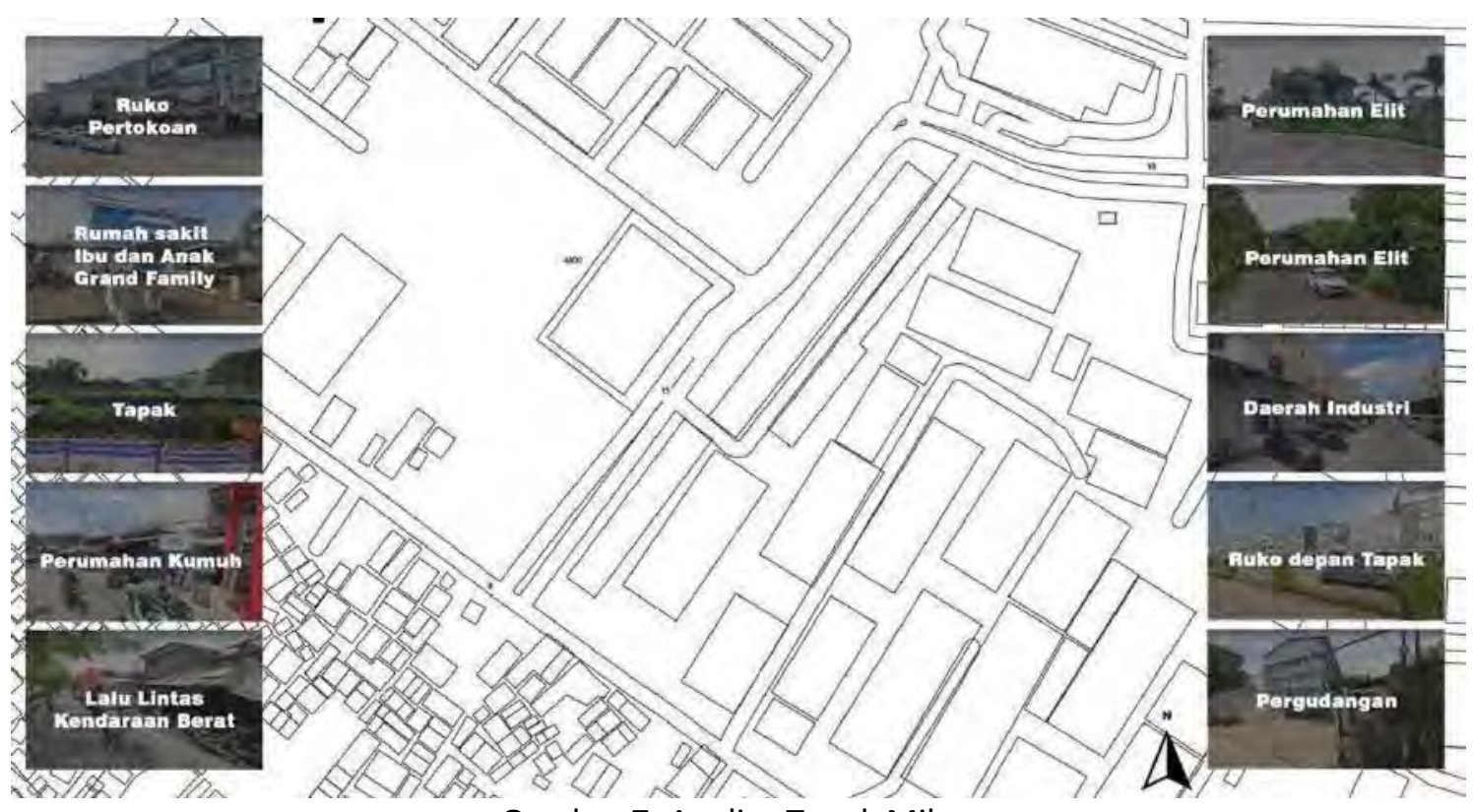

Gambar 7. Analisa Tapak Mikro

Sumber: Diolah dari Cadmapper, 2020

Daerah sekitar tapak didominasi oleh hunian menengah 2-4 Lantai, dan kawasan industri pergudangan 3-4 Lantai. Daerah ini merupakan daerah yang seringkali didatangi oleh generasi $Y$ dan Z untuk sekedar bersantai, dan bertemu teman. Hal ini sangan menguntungkan bagi Fasilitas Usaha Makanan yang mempunyai target pengunjung Generasi $Y$ dan $Z$.
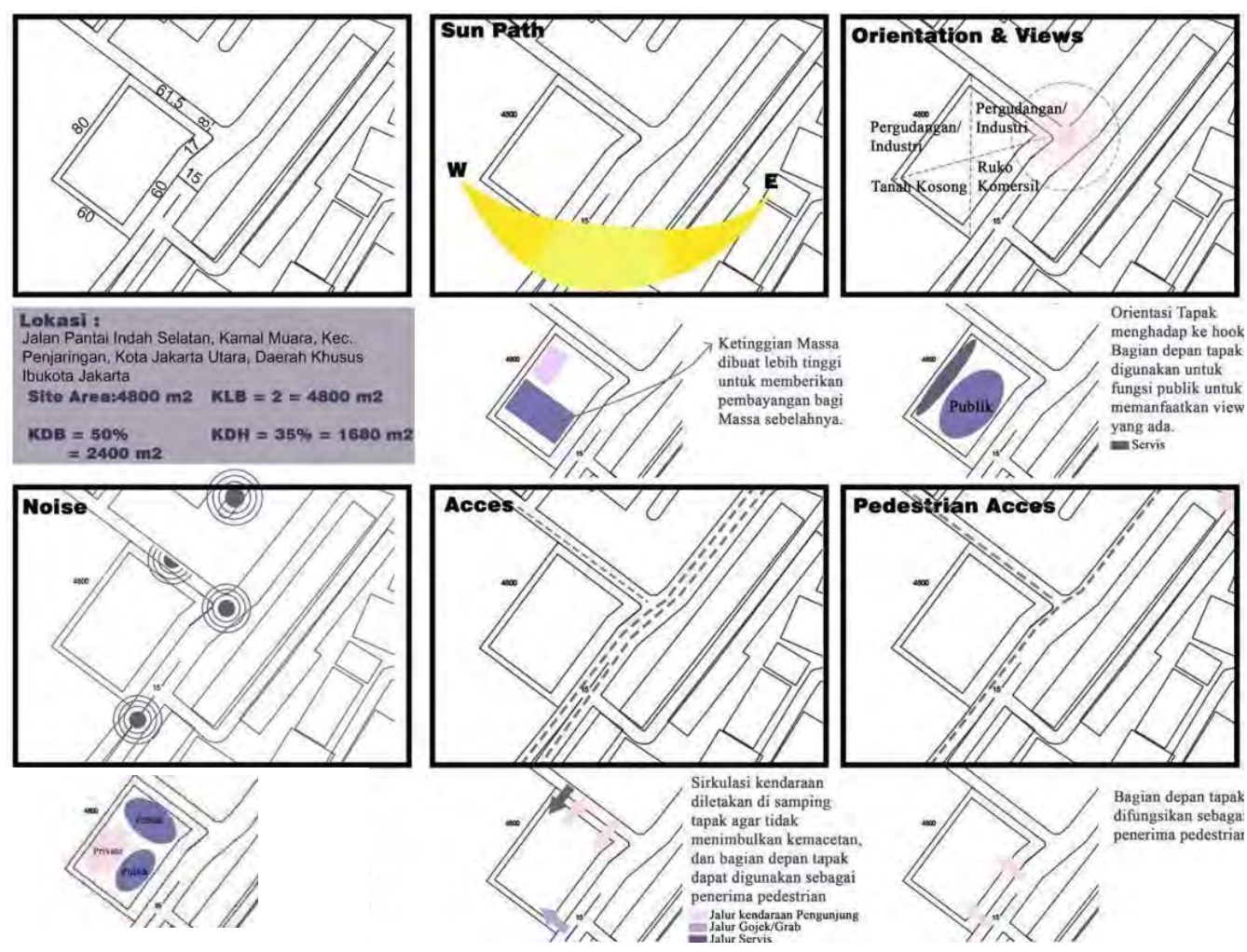

Gambar 8. Analisa Tapak Mikro

Sumber: Diolah dari Cadmapper, 2020 


\section{Konsep}

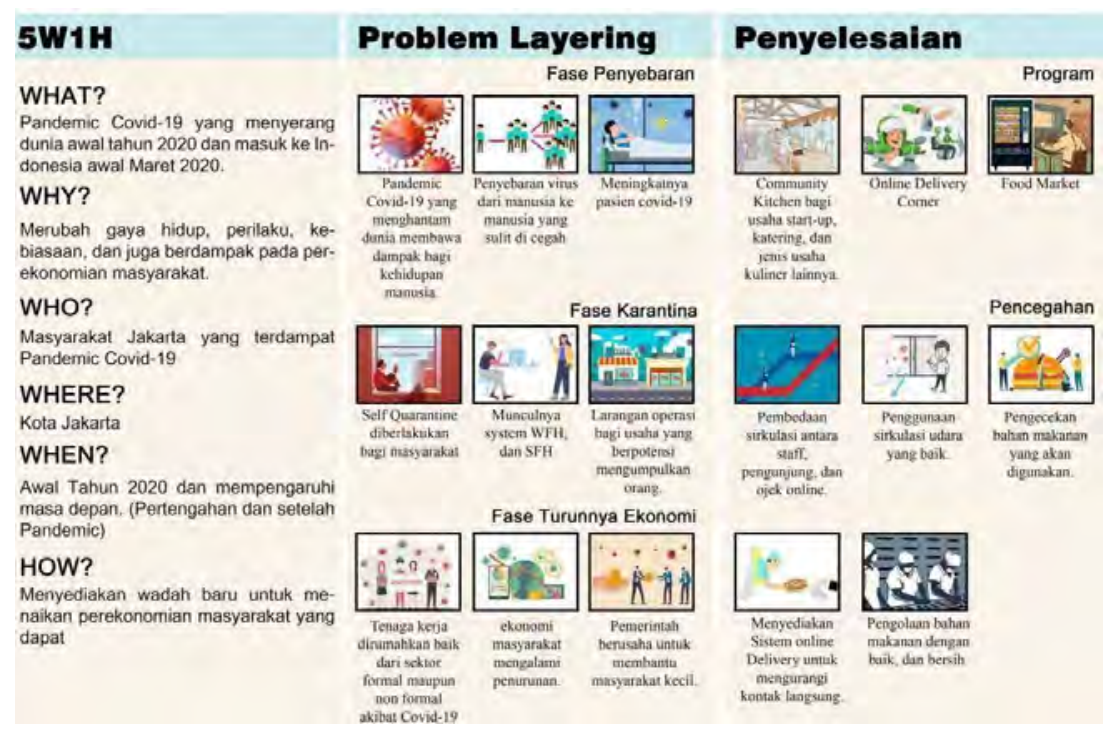

Gambar 9. Problem Layering

Sumber: Pribadi, 2020

Perancangan dilakukan dengan menjawab permasalahan, dan kebutuhan akibat dampak yang dihasilkan oleh Covid-19. Permasalahan yang ada akan dijawab melalui program yang disediakan oleh bangungan yaitu wadah untuk usaha kuliner. Sebagai pencegahan penyebaran virus, pembedaan jalur sirkulasi antar pengunjung, staff, dan ojek online diberlakukan.

\section{Proses Pembentukan Massa}

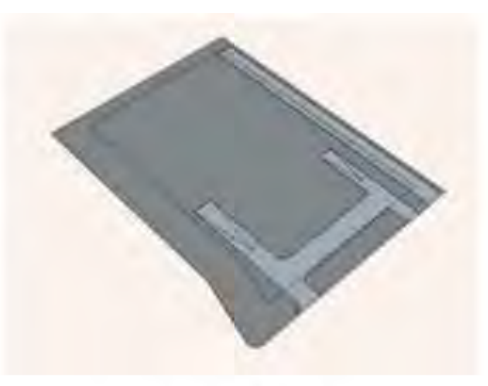

Sirkulasi

Pembentukan massa diawali dengan menentukan sirkulasi dari kendaraan. Dimana sirkulasi kendaraan diletakan di samping agar bagian depan tapak dapat digunakan untuk sirkulasi pedestrian.

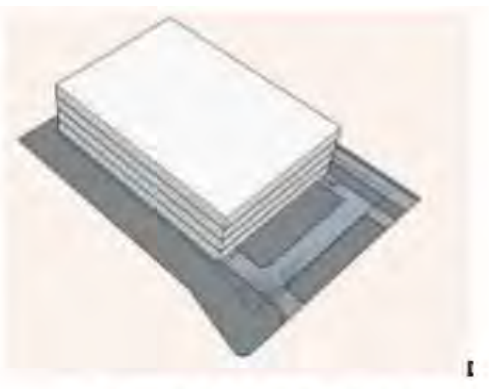

\section{Extrude dan Setback}

Bentukan awal dari massa berupa balok yang mengikuti bentuk tapak, kemudia di setback sesuai dengan ketentuan GSB.

\section{Gambar 10. Proses Gubahan Massa}

Sumber: Pribadi, 2020 


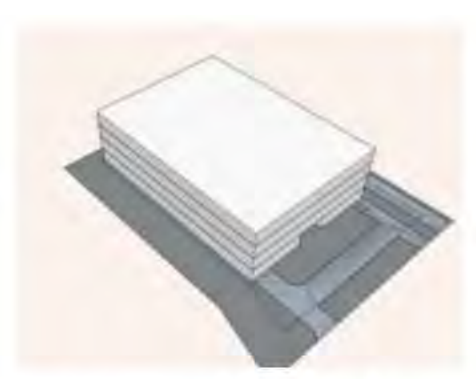

Pembagian Publik / Private

Lantai dasar massa dibagi menjadi 2 sebagai pemisah antara program yang sifatnya publik dan private, juga sebagai jalur sirkulasi pengunjung.

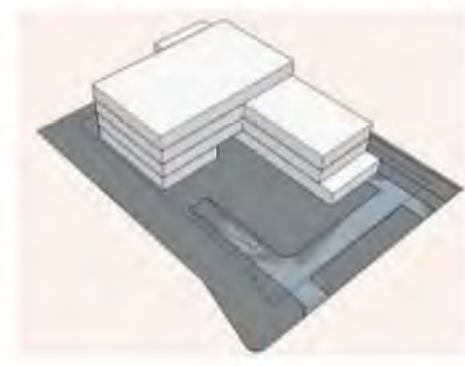

\section{Ekstensi}

Pengurangan Lantai dan ekstensi dilakukan agar tampak massa tidak monoton.

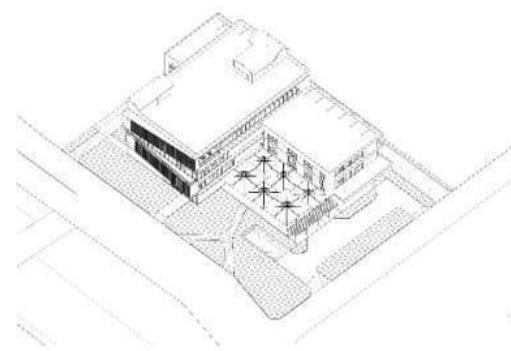

\section{Event Area}

Pada bagian kanan dimana merupakan tempat dropoff pengunjung, difungsikan sebagai area event.

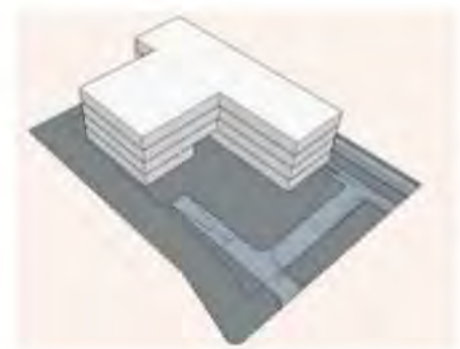

\section{Orientasi}

Pemotongan Massa dilakukan di sisi kanan untuk membuka orientasi ke hook dan memberikan pembayangan pada massa dibelakangnya. Sedangkan pada sisi kiri sebagai jalur sirkulasi ojek online.

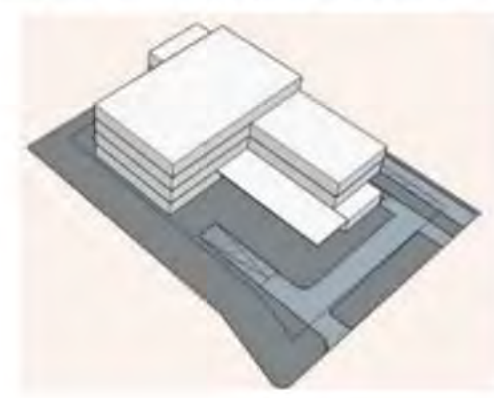

\section{Canopy}

Penambahan canopy untuk meneduhi jalur sirukulasi

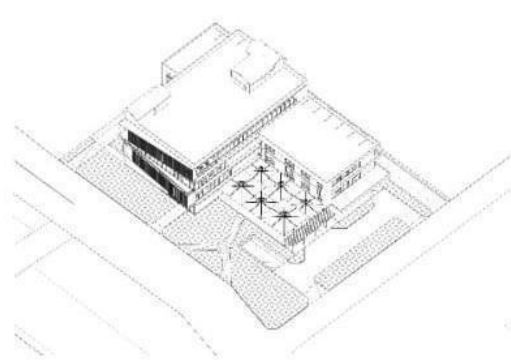

\section{Skin}

Skin kayu yang dapat digerakan pada bagian depan massa agar mendapatkan sirkulasi udara yang baik.

Gambar 11. Proses Gubahan Massa

Sumber: Pribadi, 2020

Gubahan massa terbentuk berdasarkan analisis dari keadaan sekitar tapak, dan kebutuhan dari program bangunan. Pembentukan Massa diawali dengan menentukan sirkulasi dari kendaraan bermotor, pedestrian, dan servis. Pada lantai dasar terdapat Event area yang merupakan area publik yang bersifat outdoor dan ramah bagi pejalan kaki, didalamnya terdapat retail-retail kecil yang menjajakan makanan. 


\section{Zoning}

\section{Exploded Axonometric}

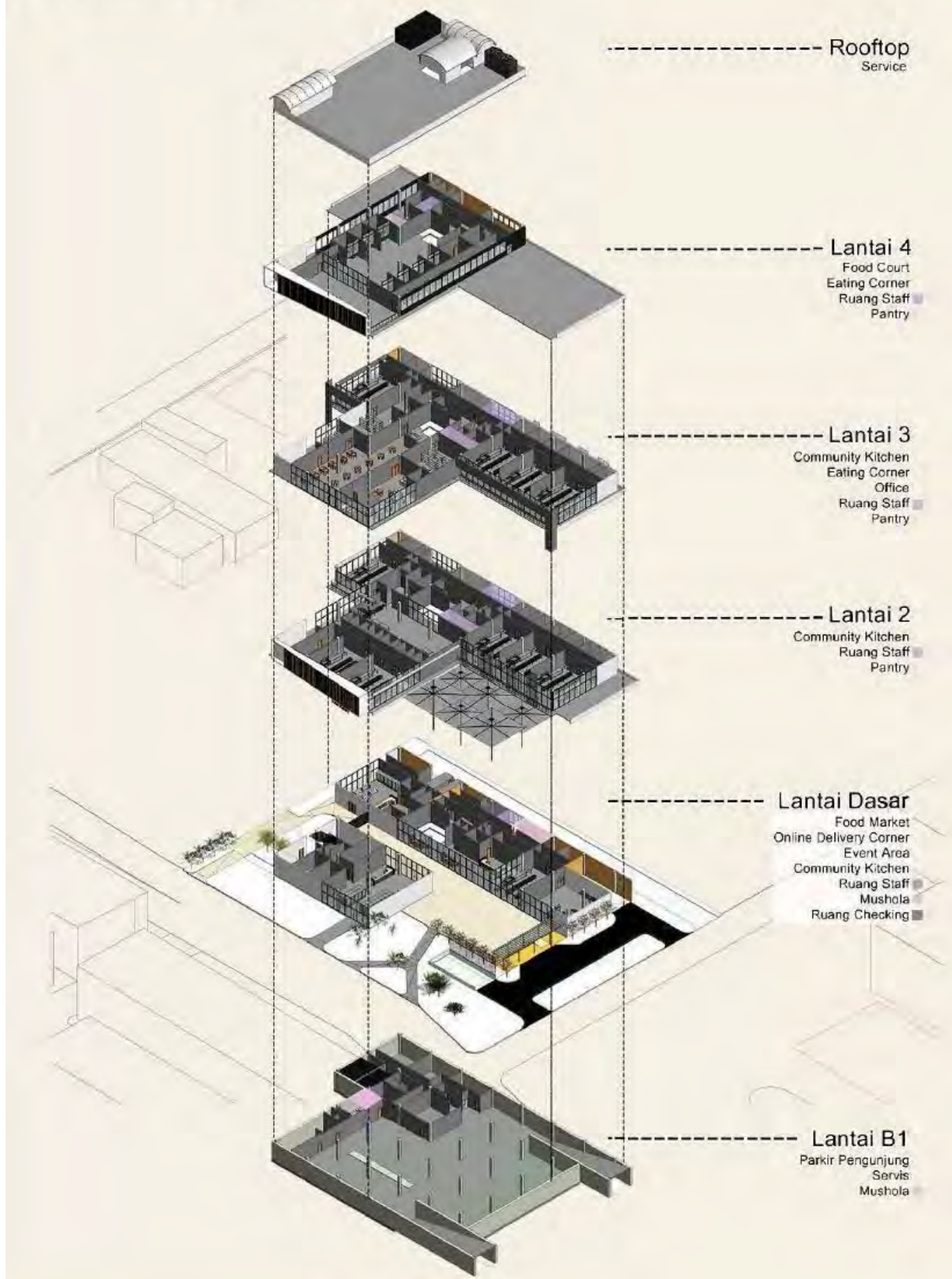

Gambar 12. Exploded Axonometric

Sumber: Pribadi, 2020

Lantai dasar diperuntukan bersifat publik dimana program yang diletakan adalah Food Market, Online delivery Corner, Event Area, dan Area Staff. Sedangkan lantai 2 dipergunakan untuk area dapur, lantai 3 dipergunakan sebagai area dapur dan eating corner, dan lantai 4 dipergunakan untukfoodstall dimana pengunjung dapat dine in. 


\section{Perspektif}
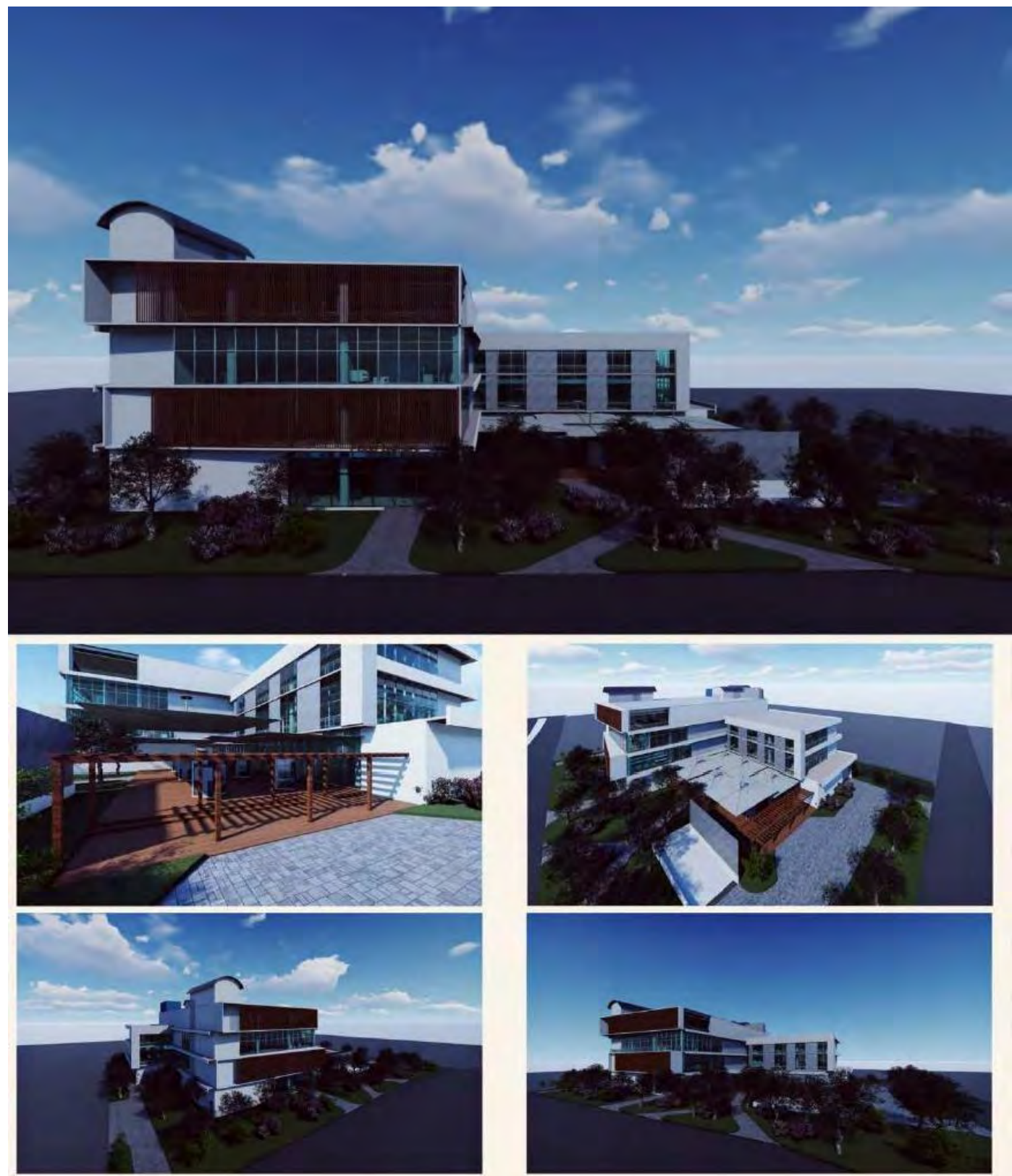

Gambar 13. Perspektif Eksterior Sumber: Pribadi, 2020

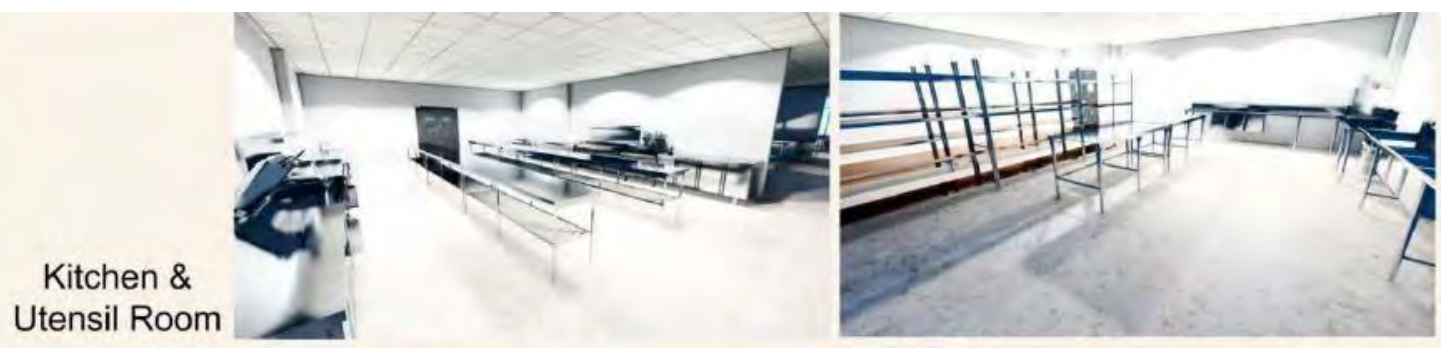

Gambar 14. Perspektif Interior

Sumber: Pribadi, 2020 


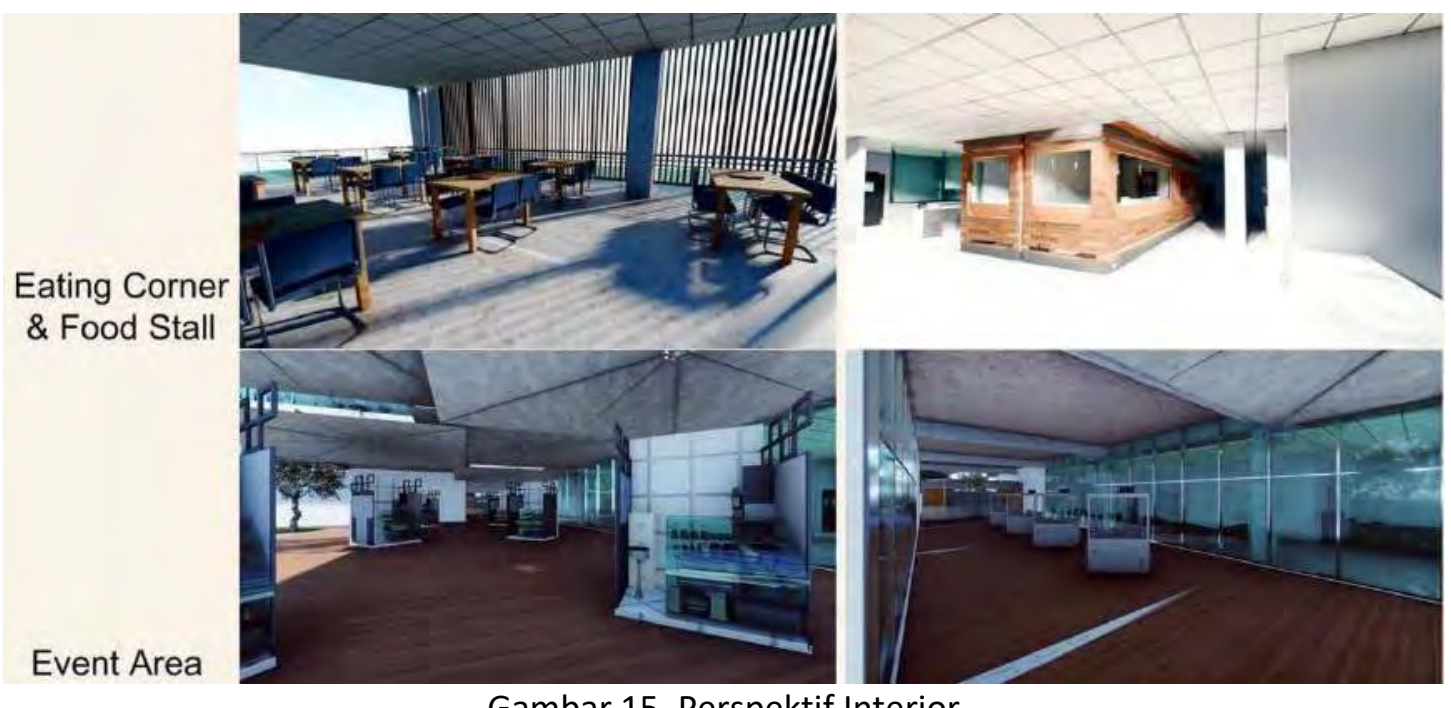

Gambar 15. Perspektif Interior

Sumber: Pribadi, 2020

\section{KESIMPULAN DAN SARAN}

\section{Kesimpulan}

Program dari Fasilitas Usaha Makanan Post Covid ini ditentukan berdasarkan hasil analisis terhadap permasalahan yang timbul akibat Pandemic Covid-19. Pandemic Covid-19 sangat memperngaruhi ekonomi masyarakat. Walaupun ekonomi terus turun, banyaknya bisnis kuliner baru yang bermunculan dapat menjadi harapan bagi ekonomi Indonesia. Program Dapur diharapkan dapat memenuhi kebuhan, dan trend dari usaha-usaha kuliner. Eating corner dipengaruhi oleh karakteristik dan minat dari generasi $Y$ dan $Z$ yang melihat dunia kuliner sebagai pilihan untuk bersenang-senang. Untuk pencegahan penyebaran virus, perancangan ini menggunakan konsep semiopen air pada eating corner ntuk memaksimalkan pengudaraan alami. Jalur sirkulasi dari pengunjung, ojek online, dan staff juga dibedakan untuk meminimalisir kontak langsung.

\section{Saran}

Pandemic Covid-19 menyebabkan munculnya kebiasaan dan gaya hidup baru. Pada masa Pandemic Covid-19 ini banyak bisnis-bisnis kuliner baru yang bermunculan, sehingga diperlukan wadah untuk memfasilitasi usaha start-up bidang kuliner tersebut. Perancangan fasilitas usaha makanan post covid-19 ini bertujuan untuk memfasilitaasi usaha start-up bidang kuliner, usaha katering, dan wirausahawan makanan lainnya, dengan memperhatikan trend yang muncul karena adanya Covid-19 ini. Perancangan ini ditujukan untuk meningkatkan perekonomian masyarakat yang terpuruk karena adanya Covid-19.

\section{REFERENSI}

Austronaldo. (2012). Mind dan Dwelling. Depok: Universitas Indonesia.

Gandha, M. V. (2020). Dwelling + Time Learn From The Past for The Future. Future Dwelling Based on Today (p. 4). Jakarta: Universitas Tarumanagara.

Hasan, A. M. (2017). Konsumsi Medsos Membentuk Pola Makan Generasi Z. Retrieved from Tirto,id: https://tirto.id/konsumsi-medsos-membentuk-pola-makan-generasi-z-ctPR Heidegger, M. (1971). Building Dwelling Thinking. In M. Heidegger, Poetry, language, thought. London: Harper and Row. 
Nurdin, R. (2017). Identifikasi Rhodamin B pada Produk Makanan Berwarna Merah yang Dijual di Pasar Johar Kota Semarang. Retrieved from Respository Universitas Muhamadiyah Semarang: http://repository.unimus.ac.id/1254/3/BAB\%20ll.pdf

Saparinto, C., \& Hidayati. (2010). Bahan Tambahan Pangan. Yogyakarta: Kanisius.

Sjarief, R. (2020). Awal Masa Depan Berhuni. Retrieved from RAW Architecture: https://realrich.org/2020/09/08/awal-masa-depan-berhuni/

Sutanto, A. (2020). Peta Metode Desain. Jakarta: Universitas Tarumanagara.

Teguh, D. (2020). Apa itu Cloud Kitchen dan Bagaimana Trennya pada 2020. Retrieved from Kipa: https://kipa.id/apa-itu-cloud-kitchen-dan-bagaimana-trennya-pada-

2020/\#: :text=Konsep\%20dapur\%20di\%20dalamnya\%20mirip,memang\%20sedang\%20po puler\%20belakangan\%20ini.\&text=Konsep\%20cloud\%20kitchen\%20yang\%20populer,yang $\% 20$ m enjual\%20ragam\%20kuliner\%20kebab.

Verdiana, B. M. (2020). HEADLINE: Pandemi Corona Ancam 130 Juta Orang di Dunia Kelaparan, Bagaimana Indonesia? Retrieved from Liputan6.com: https://www.liputan6.com/global/read/4235299/headline-pandemi-corona-ancam-130juta- orang-di-dunia-kelaparan-bagaimana-indonesia

Wahyuningrum. (n.d.). Manajemen Fasilitas. Retrieved from Staff Site Universitas Negeri Yogyakarta: http://staffnew.uny.ac.id/upload/131414327/pengabdian/C.pdf

Wednesyuda. (2020). Cloud Kitchen dan trend ke Depannya di Indonesia. Retrieved from Ultra Indonesia: https://ultraindonesia.com/newsletter/detail/cloud-kitchen-dan-trend-kedepannya-di-

indonesia\#: :text=Cloud\%20kitchen\%20sering\%20juga\%20disebut,menyediakan\%20fasilit as\%20makan\%20di\%20tempat.\&text=Konsep\%20dapur\%20di\%20dalamnya\%20mirip,me mang\%20sedang\%20po 